\title{
Public spending, currency mismatch and financial frictions*
}

\author{
Marie-Pierre Hory ${ }^{\dagger}$
}

Grégory Levieuge

\author{
Daria Onori ${ }^{\S}$
}

April 2021

\begin{abstract}
In this paper, we demonstrate that the size of the fiscal multiplier depends both on currency mismatch and home bias. Our demonstration is based on a real two-country dynamic stochastic general equilibrium model with incomplete and imperfect international financial markets, external debt and domestic financial frictions. We show that if home bias is high, the terms of trade improve following a fiscal stimulus. This reduces the private real debt burden denominated in foreign currency, decreases the external financial premium born by firms, and stimulates investment. Thus, the higher the fiscal multiplier is, the larger the proportion of firms' debt denominated in foreign currency. In contrast, the terms of trade deteriorate when home bias is low. This increases the real debt burden and external finance premium. Hence, in this case, the fiscal multiplier decreases as the share of firms' debt denominated in foreign currency increases.
\end{abstract}

JEL Classification: E62; F34; F41

Keywords: Fiscal multiplier, Terms of trade, Currency mismatch, DSGE model, Financial frictions.

*We thank the reviewers, F. Magris, J. Matheron and P. Vilieu for their helpful suggestions. Any remaining errors are ours. The views expressed in this article are those of the authors and do not necessarily reflect those of the Banque de France.

${ }^{\dagger}$ Groupe ISC Paris and LEO, Univ. Orléans, France. E-mail address: mphory@iscparis.com.

$\ddagger$ Corresponding author. Banque de France, DGEI-DEMFI-RECFIN (041-1391); 31, rue Croix des Petits Champs, 75049 Paris Cedex 01 France, and LEO, Univ. Orléans, France. E-mail address: gregory.levieuge@banque-france.fr.

§LEO, Univ. Orléans, France. E-mail address: daria.onori@univ-orleans.fr. 


\section{Introduction}

Various determinants of the size of the fiscal multiplier have been found in the literature, such as the level of public debt (Huidrom et al., 2020; Nickel and Tudyka, 2014; Ilzetzki et al., 2013; Cimadomo et al., 2010), the exchange rate regime (Born et al., 2013; Corsetti et al., 2012a), the position in the economic cycle (Gechert and Rannenberg, 2018), the degree of development, trade openness or home bias (Ilzetzki et al., 2013; Ravn et al., 2012).

In this paper, we show that the size of the fiscal multiplier may also depend on both the proportion of debt that is denominated in foreign currency and the degree of home bias. Our theoretical demonstration is based on a real two-country dynamic stochastic general equilibrium (DSGE) model with incomplete and imperfect international financial markets, external indebtedness and financial frictions due to asymmetric information. In a costly state verification framework (CSV) à la Townsend, firms have to bear an external finance premium (EFP), which increases with their debt-to-wealth ratio. While domestic net wealth is assumed to be entirely denominated in domestic goods, firms' debt is assumed to be - to some extent - denominated in foreign goods. Such a maturity mismatch may be at the origin of a financial accelerator mechanism à la Bernanke et al. (1999), which in turn influences the macroeconomic impact of fiscal shocks.

Specifically, we show that the terms of trade improve following a fiscal stimulus if home bias is high. This reduces the private real debt burden denominated in foreign goods and decreases the EFP born by firms, thus stimulating investment. It follows that the fiscal multiplier is higher the larger the fraction of firms debt denominated in foreign goods. In contrast, we observe a deterioration of the terms of trade when home bias is low. This makes the real debt burden increase, leading to a deterioration of firms' balance sheets and hence to a higher EFP. As a result, the fiscal multiplier decreases as the share of firm debt denominated in foreign goods increases.

To the best of our knowledge, this is the first contribution capable of explaining varying levels of the fiscal multiplier by combining the effects of currency mismatch, financial frictions, and real exchange rate reactions in response to fiscal stimulus. In doing so, our analysis is closely related to three branches of the literature.

First, our paper is linked to monetary DSGE models with financial frictions and sticky prices. The seminal paper of Bernanke et al. (1999) shows that in a CSV framework, the fiscal multiplier is higher when the EFP is positive. The fact that financial imperfections matter is also confirmed by more recent contributions (Fernández-Villaverde, 2010; Eggertsson and Krugman, 2012). Furthermore, our analysis builds on a two-country model where firms' debt is denominated in both domestic and foreign currencies to appraise how this influ- 
ences the size of fiscal multipliers through the EFP. Existing works assume that either firms' debt is denominated in local currency only, as in Gertler et al. (2007), or that it is entirely denominated in foreign currency, as in Chang and Velasco (2001). Batini et al. (2007) is, to the best of our knowledge, the only contribution assuming that domestic firms can borrow in both home and foreign currencies. Nonetheless, this paper does not focus on the size and determinants of the fiscal multiplier. Finally, to better focus on the basic transmission channel, we depart from these models by considering a real economy without price stickiness, similar to Cheng (2015). In fact, in an open economy, the presence of nominal rigidities coupled with a central bank following a Taylor rule has important consequences for interest rate movements following a fiscal stimulus. This, in turn, generates nominal exchange rate movements (international Fisher effect) that modify international capital flows. Ignoring nominal features and neutralizing the effects of monetary policy allows us to concentrate only on the real consequences of a fiscal shock and hence to better understand the mechanisms at work, including the changes in relative prices.

Second, in this sense, our paper also relates to the literature on the response of the terms of trade and the real exchange rate to a public spending shock. While the traditional Mundell-Fleming-Dornbush framework predicts an appreciation, recent theoretical and empirical evidence is less clear-cut. Several empirical studies find that the real exchange rate depreciates in response to an increase in public spending (Kim and Roubini, 2008; Monacelli and Perotti, 2008; Enders et al., 2011). Some recent theoretical papers support this view. However, these contributions rely on specific assumptions regarding the characteristics and behavior of public and private agents ${ }^{1}$ that may have direct effects on the fiscal multiplier, not only through the exchange rate. Bouakez and Eyquem (2015), for example, find a depreciation of the real exchange rate that is related to the assumptions of sticky prices and of a "not-too-aggressive" domestic monetary policy. Other authors show that the response of the real exchange rate can be positive or negative, conditional on factors such as the exchange rate regime, country characteristics or the nature of the fiscal shock (Corsetti et al., 2012a; Kim, 2015; Forni and Gambetti, 2016; Miyamoto et al., 2019).

Unlike this branch of the literature, we do not make any specific assumptions concerning the behavior of private and public agents, and we focus on real mechanisms. Furthermore, among country characteristics, we show that home bias plays a crucial role in the determi-

\footnotetext{
${ }^{1}$ Ravn et al. (2012) assume that the preferences of households and the government are characterized by deep habits; it is thus optimal for imperfectly competitive producers to reduce markups and prices in the short run to lock in higher demand in the future. Finally, the price of domestic consumption decreases relative to foreign consumption prices, i.e., the real exchange rate depreciates. See also Kollmann (2010) for another mechanism relying on supply-side effects. From a public debt consolidation view, Corsetti et al. (2012b) suggest that high public spending today induces expectations of future spending restraint. Thus, long-term real interest rates do not rise in response to a fiscal stimulus, and the real exchange rate depreciates.
} 
nation of relative prices. In the context of currency mismatch, the change in relative prices affects the real debt burden, which ultimately influences the macroeconomic effects of public spending.

Finally, our paper can be related to the so-called "third generation models of currency crisis" (Aghion et al., 2001, 2004; Christiano et al., 2004). In essence, this literature demonstrates that the real impact of exchange rate movements may be amplified through balance sheet effects. As a rule, countries that are most likely to enter a crisis are those in which firms hold considerable foreign currency-denominated debt. Nonetheless, our contribution differs somewhat from these models in several respects. First, we concentrate on the effects of fiscal shocks. Second, the mechanism that we focus on does not rely on public debt but on private sector debt. Third, we consider the change in the balance sheets of private domestic firms not as a cause but as a consequence of terms of trade movements.

The remainder of the paper is organized as follows. The theoretical model is developed in Section 2. Section 3 presents the calibration. Section 4 shows the responses of the model to a public spending shock, depending on the degree of home bias and maturity mismatch. A discussion on the size of the fiscal multiplier and policy implications is presented in Section 5. Section 6 concludes the paper.

\section{The model}

We consider a real economy consisting of two countries of equal size: the home economy $(\mathrm{H})$ and the foreign economy $(\mathrm{F})$. Both are populated by a continuum of identical households with size normalized to one. These households consume a composite good $\left(C_{t}\right)$, including home $\left(C_{H, t}\right)$ and foreign goods $\left(C_{F, t}\right)$. They also buy home and foreign bonds $\left(B_{H, t}\right.$ and $\left.B_{F, t}\right)$. In each bloc, there are two types of firms: capital and goods producers. To make the model as simple as possible, we assume that each of them operates in competitive markets. The capital producers buy goods and transform them into capital that is sold to goods producers. Goods producers use labor and capital to produce a homogeneous final good that they sell to households and to capital producers. Importantly, home final goods producers can borrow to finance capital input. As in Bernanke et al. (1999), because of asymmetric information, they have to bear an EFP. An important difference from Bernanke et al. (1999) is that here, firms can borrow in both local and foreign currencies. The countercyclical EFP affects firms' cost of financing, thus modifying their investment decisions and, in turn, amplifying economic fluctuations. For simplicity, and without loss of generality, we assume that there is no asymmetric information between firms and their lenders in the foreign country. Thus, there is no financial accelerator in F. 
The rest of the model is very standard. In what follows, we present the equations describing the behavior of the home country sectors in detail. The steady-state and the log-linearized version of the model are provided in the Appendix.

\section{$2.1 \quad$ Households}

We consider an infinite-horizon discrete-time economy populated by a constant mass of agents of size normalized to one in each country. The representative household in the home country is characterized by the following preferences:

$$
E_{t} \sum_{t=0}^{\infty} \beta^{t} U\left(C_{t}, L_{t}\right)
$$

where $E_{t}$ indicates the expectation operator at time $t, \beta \in(0,1)$ is the discount factor, $C_{t}$ is the per capita consumption index, and $L_{t}$ is the number of worked hours.

We assume that the utility function takes the following form:

$$
U\left(C_{t}, L_{t}\right)=\frac{C_{t}^{1-\sigma_{c}}}{1-\sigma_{c}}-\frac{L_{t}^{1+\sigma_{l}}}{1+\sigma_{l}}
$$

where $\sigma_{c}>0$ is the inverse of the intertemporal elasticity of substitution of consumption and $\sigma_{l}>0$ is the intertemporal elasticity of substitution of labor. For the sake of simplicity and to focus on the essential mechanisms, we assume that foreign households share the same preferences as households in $\mathrm{H}$.

The home household faces the following budget constraint:

$$
C_{t}+\frac{P_{H, t}}{P_{t}} B_{H, t}+\frac{P_{F, t}}{P_{t}} B_{F, t}+T_{t}=W_{t} L_{t}+R_{t-1} \frac{P_{H, t}}{P_{t}} B_{H, t-1}+\phi_{t-1}\left(d_{t-1}\right) \frac{P_{F, t}}{P_{t}} R_{t-1}^{*} B_{F, t-1}
$$

where $B_{H, t}$ and $B_{F, t}$ are risk-free one-period bonds defined in terms of goods in the home $(\mathrm{H})$ and the foreign $(\mathrm{F})$ country, ${ }^{2}$ with relative prices $\frac{P_{H, t}}{P_{t}}$ and $\frac{P_{F, t}}{P_{t}}$, respectively. $P_{H, t}$ is the price of the goods produced and sold at home, $P_{F, t}$ is the price of the goods produced in the foreign country and sold in the home economy (namely, imports), and $P_{t}$ is the domestic consumer price index $(\mathrm{CPI}) . T_{t}$ is a real lump-sum tax levied on households. $W_{t}$ represents the real wage rate. Moreover, we denote by $R_{t}$ and $R_{t}^{*}$ the real interest rates on the domestic and foreign bond markets, respectively. Generally, an asterisk "*" designates variables in the foreign economy.

The factor $\phi_{t}$ is a country premium borne by households that buy foreign bonds. Fol-

\footnotetext{
${ }^{2}$ Although the paper deals with a real economy, and hence bonds are denominated in domestic and foreign goods, throughout the paper, we will use the expression of debt denominated in domestic or foreign currency.
} 
lowing Benigno (2009) and Schmitt-Grohé and Uribe (2003), it increases with the economy's aggregate level of real foreign debt $\left(B_{F, t}\right)$ as a percentage of domestic steady-state output $d_{t}=\frac{P_{F, t} B_{F, t}}{P_{t} Y}$, and it is defined as follows:

$$
\phi_{t}\left(d_{t}\right)=\exp \left(-\phi_{d} \frac{P_{F, t} B_{F, t}}{P_{t} Y}\right)
$$

where $\phi_{d}>0$ is the country premium elasticity. We assume that $\phi^{\prime}()<$.0 . This means that the country premium increases with the aggregate level of foreign debt. In steady state, when the net foreign asset position is zero, $\phi(0)=1$. This country premium reflects frictions in international capital markets, such as the price to pay to access them, agency costs or even the possibility of default, and ensures the stationarity of the model (Schmitt-Grohé and Uribe, 2003). For analytical convenience, and without loss of generality, we suppose that home households can hold foreign bonds but that foreign households cannot hold home bonds (Benigno and Thoenissen, 2008).

The representative household chooses $C_{t}, L_{t}, B_{H, t}$ and $B_{F, t}$ to maximize her utility subject to the budget constraint, leading to the following first-order conditions:

- Consumption and leisure are chosen to equalize the marginal rate of substitution between consumption and leisure to the real wage:

$$
\frac{L_{t}^{\sigma_{l}}}{C_{t}^{-\sigma_{c}}}=W_{t}
$$

- The Euler equation, reflecting the household's taste for consumption smoothing:

$$
R_{t}=\frac{1}{\beta} E_{t}\left[\frac{C_{t}^{-\sigma_{c}}}{C_{t+1}^{-\sigma_{c}}}\right]
$$

- The arbitrage equation between home and foreign bonds:

$$
E_{t}\left[R_{t} \frac{P_{H, t+1}}{P_{H, t}}-\phi_{t}(.) R_{t}^{*} \frac{P_{F, t+1}}{P_{F, t}}\right]=0
$$

Finally, the standard transversality conditions must hold.

The per capita index of consumption, $C_{t}$, is an aggregate of consumption goods produced in the home country $\left(C_{H, t}\right)$ and consumption goods produced in the foreign country $\left(C_{F, t}\right)$. It is defined as follows:

$$
C_{t}=\left[w^{1 / \mu} C_{H, t}^{(\mu-1) / \mu}+(1-w)^{1 / \mu} C_{F, t}^{(\mu-1) / \mu}\right]^{\mu /(\mu-1)}
$$


where $\mu>0$ is the elasticity of substitution between home and foreign goods and $w \in(0,1)$ captures the degree of home bias in the home bloc. Therefore, $(1-w)$ can be viewed as the degree of trade openness. The domestic and foreign demands for domestic goods are given by

$$
C_{H, t}=w\left(\frac{P_{H, t}}{P_{t}}\right)^{-\mu} C_{t} ; \quad C_{F, t}=(1-w)\left(\frac{P_{F, t}}{P_{t}}\right)^{-\mu} C_{t}
$$

The CPI associated with the consumption index (Equation 8) is given by

$$
P_{t}=\left[w\left(P_{H, t}\right)^{1-\mu}+(1-w)\left(P_{F, t}\right)^{1-\mu}\right]^{1 /(1-\mu)}
$$

In the same way, the foreign economy's CPI is defined as

$$
P_{t}^{*}=\left[\left(1-w^{*}\right)\left(P_{H, t}^{*}\right)^{1-\mu^{*}}+w^{*}\left(P_{F, t}^{*}\right)^{1-\mu^{*}}\right]^{1 /\left(1-\mu^{*}\right)}
$$

where $P_{F, t}^{*}$ is the price of goods produced and sold in the foreign country and $P_{H, t}^{*}$ is the price of goods produced by the home economy and sold in the foreign country, namely, the price of the home economy's exports.

We define the terms of trade $\left(\tau_{t}\right)$ as the relative price of imports to exports. Given the law of one price, according to which $\frac{P_{F, t}^{*}}{P_{F, t}}=\frac{P_{H, t}^{*}}{P_{H, t}}=1$, the terms of trade can be expressed as:

$$
\tau_{t}=\frac{P_{F, t}}{P_{H, t}} .
$$

Finally, using Equations (7) and (12), the (modified) uncovered interest rate parity (UIP) condition is obtained:

$$
R_{t}=\phi_{t}\left(d_{t}\right) E_{t}\left(R_{t}^{*} \frac{\tau_{t+1}}{\tau_{t}}\right)
$$

which differs from the standard UIP because of the presence of the interest rate premium $\phi_{t}$.

\subsection{Firms}

Both countries are populated by good and capital producers. To produce final goods, goods producers use labor provided by households and capital provided by capital producers. Domestic goods producers borrow in home and foreign goods to finance their inputs and bear an EFP that depends on their balance sheet structure, in line with the framework suggested by Bernanke et al. (1999). For the sake of simplicity, foreign firms are not subject to balance sheet effects and are only financed by households of country F, without agency premium. They all operate in competitive markets. 


\subsubsection{Capital producers}

To produce new capital $K_{t}$, capital producers invest a composite of final goods (denoted $I_{t}$ ) bought from home and foreign goods producers as follows:

$$
I_{t}=\left[w_{i}^{1 / \mu_{i}} I_{H, t}^{\frac{\mu_{i}-1}{\mu_{i}}}+\left(1-w_{i}\right)^{1 / \mu_{i}} I_{F, t}^{\frac{\mu_{i}-1}{\mu_{i}}}\right]^{\frac{\mu_{i}}{\mu_{i}-1}}
$$

where $w_{i} \in(0,1)$ measures the home bias of capital producers and $\mu_{I}>0$ is the elasticity of substitution between home and foreign retail goods for capital producers. In producing new capital, these firms support internal adjustment costs, which are increasing and convex in $I_{t} / K_{t}$ :

$$
\Psi\left(I_{t}, K_{t}\right)=\frac{\Phi}{2}\left(\frac{I_{t}}{K_{t}}-\delta\right)^{2} K_{t}
$$

where $\delta \in(0,1)$ is the depreciation rate of capital and $\Phi$ is a positive parameter.

For the sake of simplicity, we assume that firms and households have the same preferences for home and foreign goods, such that $w=w_{i}$ and $\mu=\mu_{i}$. The price of $I_{t}$ is therefore equal to the CPI given by Equation (10). Next, the optimal intratemporal demands for domestic and foreign inputs are given by

$$
I_{H, t}=w\left(\frac{P_{H, t}}{P_{t}}\right)^{-\mu_{i}} I_{t} \quad \text { and } \quad I_{F, t}=(1-w)\left(\frac{P_{F, t}}{P_{t}}\right)^{-\mu_{i}} I_{t}
$$

Finally, the stock of capital evolves according to the usual law of motion:

$$
K_{t+1}=I_{t}+(1-\delta) K_{t}
$$

Hence, profit optimization of capital producers with respect to $I_{t}$ defines the real price of capital, $q_{t}$, as follows:

$$
q_{t}=1+\frac{\partial \Psi\left(I_{t}, K_{t}\right)}{\partial I_{t}}=1+\Phi\left(\frac{I_{t}}{K_{t}}-\delta\right)
$$

\subsubsection{Goods producers}

Domestic firms use capital and labor to produce and sell a homogeneous good in a competitive market. Their production technology is characterized by constant returns to scale and is represented by a Cobb-Douglas function with exogenous productivity shocks denoted $A_{t}$ :

$$
Y_{t}=A_{t} K_{t}^{\alpha} L_{t}^{1-\alpha}
$$


where $Y_{t}$ is the quantity of goods produced by domestic firms. The capital intensity, $\alpha$, lies between 0 and 1 . These firms choose the quantities of labor and capital that maximize their profits. This yields the following first-order conditions, defining domestic real wages:

$$
W_{t}=\frac{P_{H, t}}{P_{t}}(1-\alpha) \frac{Y_{t}}{L_{t}}
$$

and the real return on capital over period $t$ :

$$
R_{t}^{k}=\left[\frac{\alpha \frac{P_{H, t}}{P_{t}} \frac{Y_{t}}{K_{t}}-\frac{\Phi}{2}\left[\delta^{2}-\left(\frac{I_{t}}{K_{t}}\right)^{2}\right]+(1-\delta) q_{t}}{q_{t-1}}\right]
$$

Equation (21) states that each additional unit of capital yields $\alpha \frac{P_{H, t}}{P_{t}} \frac{Y_{t}}{K_{t}}$ (corresponding to the marginal productivity of capital) to the firm minus the capital adjustment costs. This equation also assumes that capital could be resold at its depreciated value $(1-\delta) q_{t}$.

Home wholesalers borrow in both local and foreign currencies to finance their activity (contrary to foreign wholesale firms). Moreover, as in Bernanke et al. (1999), they have to bear an EFP, $\Theta_{t}$, defined by

$$
\Theta_{t}=\Theta\left(\frac{q_{t-1} K_{t}}{N_{t}}\right)
$$

with $\Theta^{\prime}()>0,. \Theta(1)=1$ and $\Theta(\infty)=\infty$. $N_{t}$ is the net worth of a wholesale firm, which will be defined below. Moreover, the elasticity of the EFP to the capital-to-net worth ratio is denoted $\theta$ hereafter.

The representative firm borrows in home currency in proportion $\kappa$ and in foreign currency ${ }^{3}$ in proportion $(1-\kappa)$, with $\kappa \in[0,1]$. Therefore, home and foreign interest rates are combined to obtain the expected marginal cost of borrowing:

$$
E_{t}\left(R_{t+1}^{k}\right)=\Theta_{t+1}\left[\kappa R_{t}+(1-\kappa) \phi_{t}\left(d_{t}\right) E_{t}\left(R_{t}^{*} \frac{\tau_{t+1}}{\tau_{t}}\right)\right]
$$

This equation states that the real return of capital must be equal to the cost of acquiring this capital. This cost is determined by the EFP, by the home interest rate in proportion $\kappa$, and by the foreign interest rate and the terms of trade in proportion $1-\kappa$.

Wholesalers accumulate net worth according to the following dynamics:

$$
N_{t+1}=\xi_{e}\left[R_{t}^{k} q_{t-1} K_{t}-\Theta_{t}\left[\kappa R_{t-1}+(1-\kappa) \phi_{t-1}\left(d_{t-1}\right) R_{t-1}^{*} \frac{\tau_{t}}{\tau_{t-1}}\right]\left(q_{t-1} K_{t}-N_{t}\right)\right]
$$

\footnotetext{
${ }^{3}$ Explaining $\kappa$ is beyond the scope of this paper. Nonetheless, an interesting extension would consist of rendering it endogenous.
} 
where $1-\xi_{e}$ is the probability that a firm will exit the market. The net worth is equal to the real return on capital held by the firm minus the financing cost of the acquired capital. Equation (24) shows that firms are exposed to changes in the terms of trade when they are indebted in foreign currency. For small values of $\kappa$, a decrease in the terms of trade (an appreciation) increases the firm's net worth, whereas an increase in the terms of trade (a depreciation) decreases its net worth.

Finally, entrepreneurs who exit consume their remaining resources:

$$
C_{t}^{e}=\frac{\left(1-\xi_{e}\right)}{\xi_{e}} N_{t}
$$

In line with households, the optimal consumption of exiting entrepreneurs is

$$
C_{H, t}^{e}=w\left(\frac{P_{H, t}}{P_{t}}\right)^{-\mu} C_{t}^{e} ; \quad C_{F, t}^{e}=(1-w)\left(\frac{P_{F, t}}{P_{t}}\right)^{-\mu} C_{t}^{e}
$$

\subsection{Fiscal policy and market clearing}

As is typical in the literature, public spending is financed through lump-sum taxes:

$$
P_{t} G_{t}=T_{t}
$$

where $G_{t}$ is the total amount of public spending. We assume that the government consumes both local and foreign final goods and that composite public spending is aggregated in the same manner as private demand. Public spending follows an autoregressive process:

$$
\widehat{G}_{t}=\rho_{g} \widehat{G}_{t-1}+\varepsilon_{g_{t}}
$$

where $\widehat{G}_{t}=\frac{G_{t}-G}{G}$ is the log-deviation of $G_{t}$ around its steady-state value $G, \rho_{g} \in(0,1)$, and $\varepsilon_{g_{t}}$ is a fiscal shock.

The domestic market clearing condition is given by

$$
Y_{t}=w\left(\frac{P_{H, t}}{P_{t}}\right)^{-\mu}\left(C_{t}+C_{t}^{e}+I_{t}+G_{t}\right)+(1-w)\left(\frac{P_{H, t}^{*}}{P_{t}^{*}}\right)^{-\mu}\left(C_{t}^{*}+I_{t}^{*}+G_{t}^{*}\right)
$$

The equilibrium between the current account and the financial account allows the trade balance $(T B)$ to be defined as follows:

$$
T B_{t}=P_{H, t} Y_{t}-P_{t} C_{t}-P_{t} C_{t}^{e}-P_{t} I_{t}-P_{t} G_{t}-P_{t} \Psi\left(I_{t}, K_{t}\right)
$$


The home economy accumulates net foreign assets according to the following dynamics:

$$
d_{t}=\frac{P_{t-1}}{P_{t}} \frac{P_{H, t}}{P_{H, t-1}} \phi_{t-1} \frac{\tau_{t}}{\tau_{t-1}} R_{t-1}^{*} d_{t-1}+\frac{P_{H, t}}{P_{t}} \frac{Y_{t}}{Y}-\frac{C_{t}}{Y}-\frac{C_{t}^{e}}{Y}-\frac{G_{t}}{Y}-\frac{I_{t}}{Y}-\Psi\left(I_{t}, K_{t}\right)
$$

Walras' law implies that the bond market equilibrium is reached when all other markets clear.

\section{Calibration}

The parameters of the model are calibrated with respect to consensus values in the literature. As noted above, the main differences between the two economies concern the financial accelerator mechanism (absent in country $\mathrm{F}$ for parsimony) and the denomination of debt (to varying degrees in foreign currency for country $\mathrm{H}$ but in domestic currency in $\mathrm{F}$ ). As such, we can more clearly isolate the mechanisms at work and the impact of foreign currency denomination of debt on the fiscal multiplier. A complete summary of the parameter calibration is reported in Table 1 below. Note that for the sake of the analysis, some different values of $\kappa$ and $\omega$ will be considered.

Table 1: Baseline calibration of the parameters

\begin{tabular}{|c|c|c|c|}
\hline Parameter & Definition & Value & Source \\
\hline$\sigma_{c}$ & $\begin{array}{l}\text { Inverse of intertemporal elasticity of substi- } \\
\text { tution of consumption }\end{array}$ & 2 & Elekdağ and Tchakarov (2007) \\
\hline$\sigma_{l}$ & Inverse of Frisch elasticity of labor supply & 1 & Elekdağ and Tchakarov (2007) \\
\hline$\beta$ & Discount factor & 0.99 & Usual \\
\hline$\phi_{d}$ & Country premium elasticity & 0.0007 & Schmitt-Grohé and Uribe (2003) \\
\hline$\zeta$ & Elasticity of substitution between varieties & 6 & $\begin{array}{l}\text { Bouakez and Eyquem (2015) and } \\
\text { Kitano and Takaku (2015) }\end{array}$ \\
\hline$\alpha$ & Capital intensity & 0.30 & Kitano and Takaku (2015) \\
\hline$\delta$ & Depreciation rate of capital & 0.025 & Usual \\
\hline$\mu$ & $\begin{array}{l}\text { Elasticity of substitution across domestic and } \\
\text { foreign goods }\end{array}$ & 1.5 & $\begin{array}{l}\text { Bouakez and Eyquem (2015), Ki- } \\
\text { tano and Takaku (2015) }\end{array}$ \\
\hline$\Phi$ & Adjustment cost function parameter & 6 & Chang and Fernández (2013) \\
\hline$\theta$ & $\begin{array}{l}\text { Elasticity of external finance premium to the } \\
\text { capital-to-net wealth ratio }\end{array}$ & 0.075 & Elekdağ and Tchakarov (2007) \\
\hline$\xi_{e}$ & Probability of firms to exit & 0.985 & Levieuge (2009) \\
\hline$\rho_{g}$ & Autocorrelation of public spending shocks & 0.8 & Usual \\
\hline
\end{tabular}


Households Following Elekdağ and Tchakarov (2007), the inverse of the intertemporal elasticity of substitution $\left(\sigma_{c}\right)$ and the inverse of the Frisch elasticity of labor supply $\left(\sigma_{l}\right)$ are fixed at 2 and 1 , respectively. As is typical in the literature, the discount factor $\beta$ is equal to 0.99 . The elasticity of substitution between locally produced varieties, $\zeta$, is equal to 6 , following Bouakez and Eyquem (2015) and Kitano and Takaku (2015). The elasticity of substitution between home and foreign goods, $\mu$, is fixed at 1.5, as in Bouakez and Eyquem (2015). Next, the consumption-to-GDP ratio $(C / Y)$ in steady state is fixed at $60 \%$. Finally, the country premium elasticity $\phi_{d}$ is assumed to be equal to 0.0007 , in line with SchmittGrohé and Uribe (2003).

Firms Following Kitano and Takaku (2015), the capital intensity $(\alpha)$ is set to 0.35, which implies a labor intensity of 0.65 . As is typical in the literature, the depreciation rate of capital $\delta$ is set to 0.025 . The adjustment cost function parameter $\Phi$ is equal to 6 , as in Chang and Fernández (2013).

Wholesale firms support an EFP, which depends on the capital-to-net worth ratio with an elasticity of 0.075 , in line with Elekdağ and Tchakarov (2007), for example. Wholesalers exit at the end of a period with probability $1-\xi_{e}$, with $\xi_{e}=0.985$, as in Levieuge (2009). In steady state, the consumption of existing firms $\left(C^{e}\right)$ is assumed to represent $2 \%$ of GDP. In steady state, the leverage ratio $(K / N)$ is equal to 3 , following Devereux et al. (2006), whereas investment represents $18 \%$ of GDP. ${ }^{4}$

Fiscal policy The autoregressive parameter $\rho_{g}$ in the process driving the pattern of public spending shocks is set to 0.8 , in line with most of the literature.

\section{The effects of public spending}

This section presents the real effects of public spending, especially on GDP, depending on the degree of home bias and on the proportion of external debt denominated in foreign currency. Because, according to the literature, the degree of home bias may influence the reaction of the real exchange rate to public spending, our analysis is conducted in two stages: we successively consider the case of an economy with a large and with a low home bias, i.e., with $\omega=0.75$ or 0.25 , respectively. In each case, we examine the effects of a low vs. high share of debt denominated in foreign currency. Additionally, to be as clear as possible, we also refer to a configuration without financial friction, i.e., with $\theta=0$ (i.e., no financial

\footnotetext{
${ }^{4}$ For the foreign economy, $I^{*} / Y^{*}$ is set to $20 \%$ since $C^{e} / Y$ is zero.
} 
accelerator). Considering these different configurations allows for a better understanding of the mechanisms at work and of the results.

As a preamble, note that financial frictions are an important feature of the model. In this respect, Equation (22), which defines the EFP, is crucial: it states that the EFP is decreasing in net wealth ("collateral effect") and increasing in $q_{t-1} K_{t}$ ("capital demand effect"). An important inherent mechanism to bear in mind, which is common to all the configurations under review, is the following: any decrease (increase) in investment induces less (more) capital accumulation and thus less (more) net wealth accumulation, which tends to increase (decrease) the EFP. This in turn exacerbates the initial decline (increase) in investment.

Finally, notwithstanding financial frictions, the effects of public spending are not expected to be highly beneficial in this model in real terms, notably given Ricardian households and the absence of nominal rigidities. Crowding-out effects of private investment are likely to be strong.

\subsection{Large home bias}

We first consider the case of an economy with an important home bias $(\omega=0.75)$. Figure 1 reports the responses of the main variables of the model to a $1 \%$ increase in public spending. The red dotted line corresponds to the case in which firms are mainly indebted in foreign currency $(\kappa=0.1)$, while the blue solid line refers to a situation in which indebtedness is mainly denominated in local currency $(\kappa=0.9)$.

In the two cases, the increase in public spending triggers an increase in domestic demand, given the home bias, and thus a rise in domestic prices $P_{H, t}$. This in turn has two effects. First, it makes domestic investment more expensive, as the price of $I_{t}$ is equal to the CPI given by Equation (10). This drives down domestic investment, as well as total investment, given the predominant weight of $I_{H}$ in $I_{t}(\omega=0.75$ in Equation 14). This is the first source of the crowding-out effect.

Second, the increase in $P_{H, t}$ improves the terms of trade. ${ }^{5}$ Interestingly, this reduces the real debt burden when debt is mainly denominated in foreign currency (i.e., when $\kappa=0.1$ ). In this case, firms' net worth increases, and as the collateral effect dominates the capital demand effect, firms benefit from a decrease in the EFP. As this mitigates the crowding-out effect, the response of the output to the fiscal shock is strictly positive. Given these favorable balance sheet effects, this configuration results in the highest multiplier that can be expected.

\footnotetext{
${ }^{5}$ Note that, by construction, a decrease in $\tau$ indicates an improvement in the terms of trade.
} 
Figure 1: Impulse response functions to a $1 \%$ increase in public spending when $\omega=0.75$
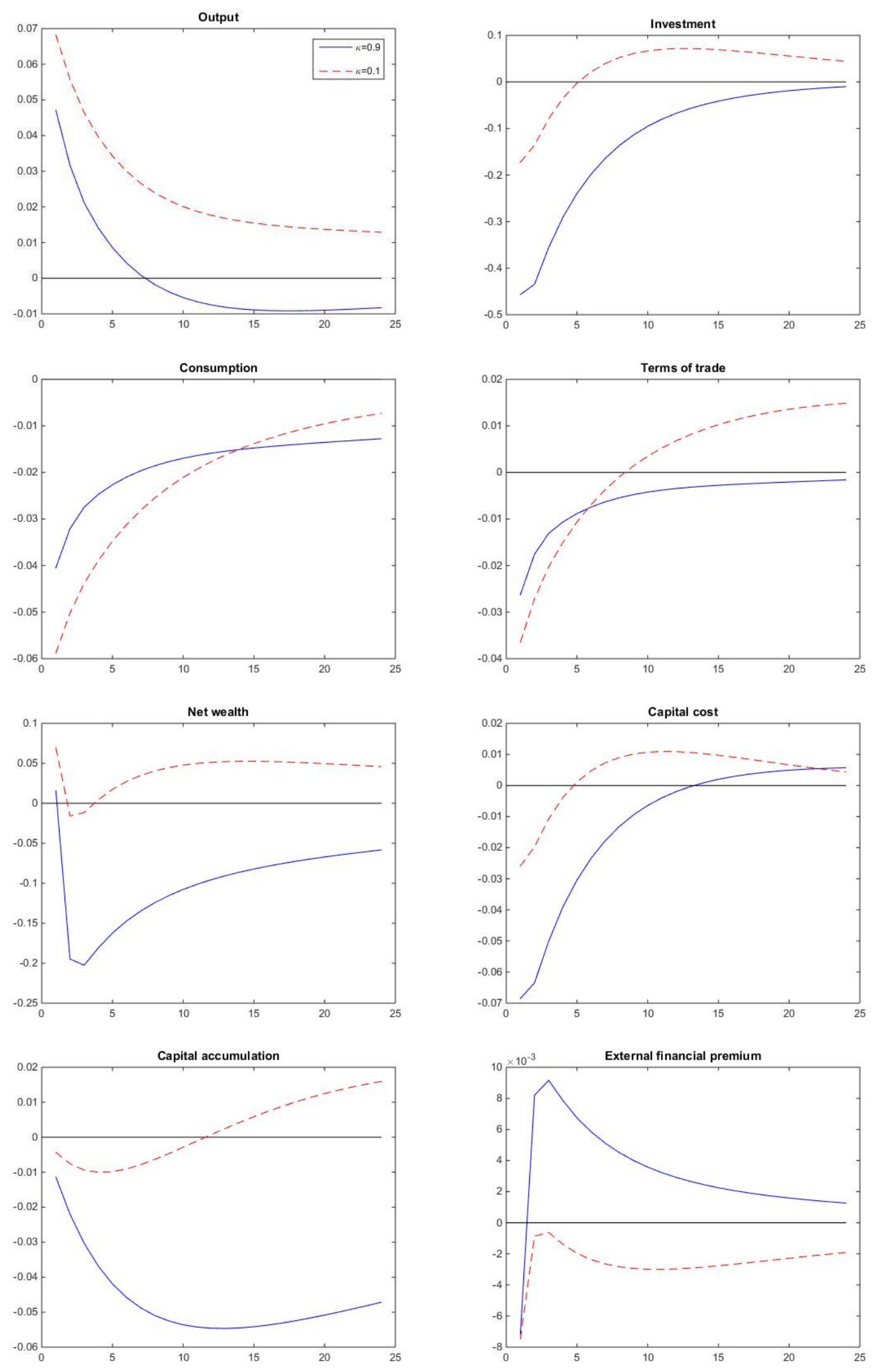
For comparison purposes, Figure 4 in the Appendix shows that in the absence of financial frictions $(\theta=0)$, net wealth initially increases but without affecting credit conditions (by definition). Hence, the economy cannot benefit from any self-sustained positive balance sheet effects. As a result, net worth declines in the wake of reduced capital accumulation, and output is less stimulated than in the presence of the financial accelerator mechanism.

Finally, when the real debt burden consists primarily of domestic goods (i.e., $\kappa=0.9$ ), the improvement in the terms of trade has no effect on the balance sheets of indebted firms.Therefore, the crowding-out effect is not dampened, contrary to the case in which $\kappa=0.1$. Consequently, output increases to a lesser extent (by $32 \%$ less) than when real debt is mainly denominated in foreign currency. It even decreases five quarters after the shock, given the stronger decline in private investment.

\subsection{Low home bias}

We now assume that the domestic economy is characterized by a low home bias, or equivalently, by a large openness, with $\omega=0.25$. The impulse responses of the main variables of the model, under this configuration, are presented in Figure 2, conditional on low $(\kappa=0.9)$ and high $(\kappa=0.1)$ debt in foreign currency.

In this context of low home bias, an increase in public spending raises the demand for foreign goods. This increases the foreign goods price $\left(P_{F, t}\right)$, with two main consequences. First, given that the price of investment goods $I_{t}$, given by Equation (10), is mainly driven by the price of goods produced in the foreign country (as $1-\omega=0.75$ ), the rise in $P_{F, t}$ increases the price of investment goods $I_{t}$. This drives down investment. Moreover, the subsequent decline in capital and wealth accumulation tends to increase the EFP. This worsens the crowding-out effect. Second, we observe a deterioration in the terms of trade, which has different consequences depending on the proportion of private debt that is denominated in foreign goods.

When debt is mainly denominated in foreign currency $(\kappa=0.1)$, the deterioration in the terms of trade increases the real debt burden. The worsening of firms' balance sheet position provokes a tightening of credit conditions, with a higher EFP. This contributes making investment even lower. As a result, we observe an immediate decrease in aggregate output in response to a fiscal shock. This depicts the worst configuration in terms of the fiscal multiplier. ${ }^{6}$

\footnotetext{
${ }^{6}$ The deterioration in the terms of trade and, therefore, the negative balance sheet effects are limited by the decline in output, as this implies less demand (abroad). However, this remains the worst case.
} 
Figure 2: Impulse response functions to a $1 \%$ increase in public spending when $\omega=0.25$
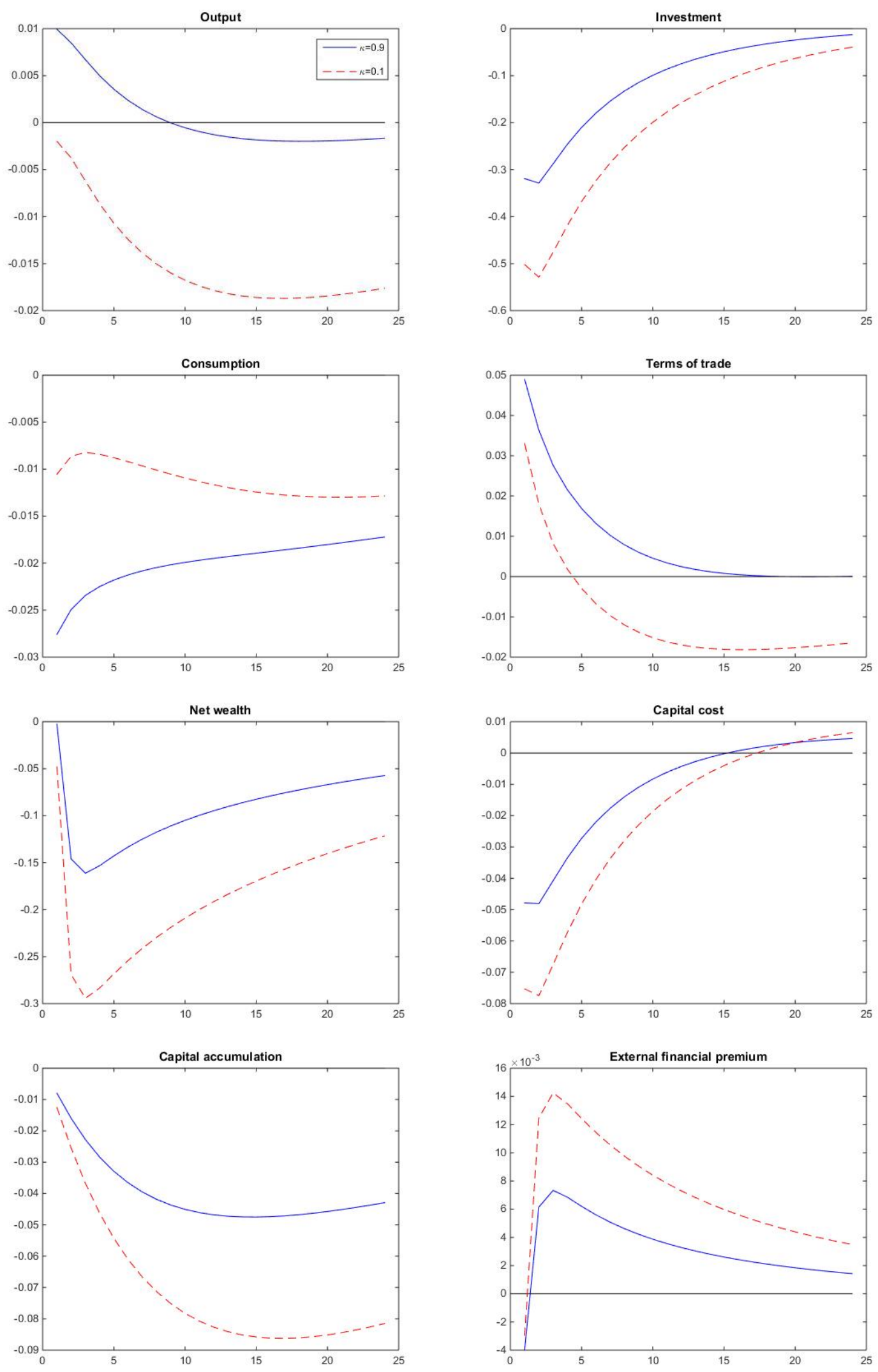
In contrast, we observe in Figure 5 in the Appendix that the response of output is not negative but positive in the absence of financial frictions, as investment does not suffer from the deterioration of firms' balance sheets. Once again, this demonstrates the importance of financial frictions in explaining the size (and even the sign) of the fiscal multiplier in an open economy with debt denominated in foreign currency.

Finally, when private debt consists primarily of domestic goods $(\kappa=0.9)$, credit conditions are tightened due to lower accumulation of capital and, hence, of net worth (as the collateral effect dominates the demand effect) in the wake of the increase in the price of investment. However, the EFP increases less than for $\kappa=0.1$, as the deterioration of the terms of trade has little impact on the real debt burden. Thus, investment falls but only by half as much as in the previous case. As a result, the response of output is positive, at least during the first 10 periods after the fiscal shock.

\section{Assessment and discussion of policy implications}

Following convention in the literature, the responses of GDP are now transposed in terms of the fiscal multiplier, defined as $\Delta Y_{t} / \Delta G_{t}$. Figure 3 represents this impact multiplier conditional on the degree of home bias and on the proportion of debt denominated in domestic currency. This figure, which complements the IRFs and the mechanisms described previously, deserves several comments.

Figure 3: The fiscal multiplier against the share of domestic currency-denominated debt

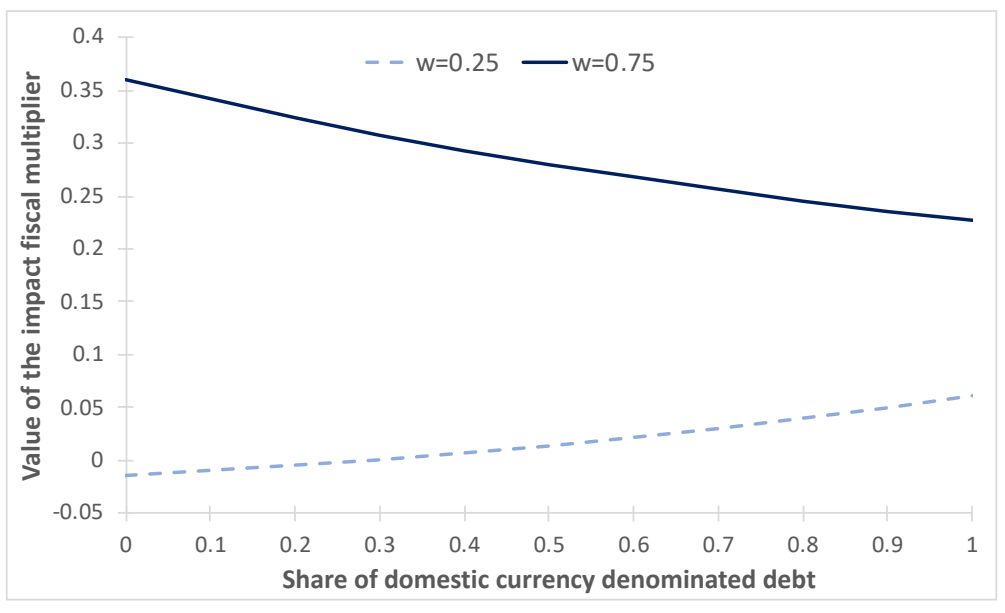

First, Figure 3 confirms that the level of the multiplier highly depends on the degree of home bias. A small home bias (dotted line) is associated with a low fiscal multiplier. This is due not only to the increase in domestic demand for imported goods, as in the textbook 
model, but also to balance sheet effects. Indeed, under financial frictions, financing conditions depend on both currency mismatch and the response of the terms of trade to public spending shocks. This is because, under low home bias, the terms of trade worsen, and the balance sheet structure of firms that are heavily indebted in foreign currency deteriorates. Negative balance sheet effects are combined with the standard crowding-out effect to make the fiscal multiplier very low. In this configuration, the higher the debt in foreign currency is, the lower the fiscal multiplier. The impact multiplier can even be negative when private debt is mainly denominated in foreign currency.

In contrast, the solid line in Figure 3 shows that being indebted in foreign goods is beneficial when home bias is strong. In this case, the terms of trade improve in the wake of an exogenous increase in public spending. Because this improves the quality of firms' balance sheets by reducing real debt, firms can benefit from better credit conditions. Hence, under this configuration, the higher the debt in foreign currency is, the higher the fiscal multiplier. Despite the absence of ingredients that are known to increase fiscal multipliers in theoretical models (e.g., nominal rigidities or zero lower bounds for policy rates) and despite the Ricardian behavior of the agents, strictly positive multipliers may be achieved in this case.

Finally, these results lead to rather nuanced normative conclusions regarding currency mismatch. ${ }^{7}$ From a fiscal multiplier perspective, policies designed to restrict debt denominated in foreign currency are not necessarily desirable. They may mitigate the crowding-out effects of public spending stimulus in the case of a small home bias. However, they may reduce the fiscal multiplier when the home bias is large.

Ultimately, the main issue concerns financial imperfections. As shown ${ }^{8}$, in the absence of financial frictions, currency mismatch is less crucial for the size of the impact of public spending.

\section{Concluding remarks}

The literature reports various determinants of the size of the fiscal multiplier, such as the level of public debt, the position of the economy in the business cycle, the exchange rate regime, or the degree of trade openness. In this paper, we demonstrate that in the presence of financial frictions, currency mismatch and the degree of home bias simultaneously constitute an additional determinant of the effectiveness of public spending.

Our theoretical contribution is based on a real two-country dynamic stochastic general

\footnotetext{
${ }^{7}$ See, e.g., IMF (2011) for examples of countries that have implemented limits on currency mismatch.

${ }^{8} \mathrm{See}$, e.g., Figure 4 in the Appendix.
} 
equilibrium model with incomplete and imperfect international financial markets and external indebtedness. The model also embeds financial frictions due to asymmetric information. Therefore, in a costly state verification framework, firms have to bear an external finance premium that increases with their debt-to-wealth ratio. While domestic net wealth is assumed to be entirely denominated in domestic goods, firms' debt is assumed to be (to some extent) denominated in foreign goods. This maturity mismatch may be at the origin of a financial accelerator mechanism that may influence the macroeconomic impact of fiscal shocks.

We show that following an exogenous increase in public spending, the terms of trade can improve or deteriorate, depending on the degree of home bias of the domestic economy. If the home bias is high, the terms of trade improve. This reduces the private real debt burden denominated in foreign currency and decreases the external finance premium born by firms. Finally, this stimulates investment. Thus, the higher the fiscal multiplier is, the larger the fraction of firms' debt denominated in foreign currency. In contrast, we observe a deterioration of the terms of trade when home bias is low. This makes the real debt burden increase, leading to a deterioration of firms' balance sheets and hence to a higher external finance premium. As a result, the fiscal multiplier decreases as the share of firms' debt denominated in foreign currency increases.

These results lead to rather nuanced conclusions for policies addressing currency mismatch. From a fiscal multiplier perspective, measures designed to restrict debt denominated in foreign currency are not necessarily desirable. On the one hand, they may mitigate the crowding-out effects of public spending stimulus in the case of small home bias. On the other hand, they may reduce the fiscal multiplier when home bias is large. Finally, financial imperfections appear even more important: in the absence of financial frictions, currency mismatch turns out to be less crucial for the size of the impact of public spending. 


\section{References}

Aghion, P., Bacchetta, P., and Banerjee, A. (2001). Currency crises and monetary policy in an economy with credit constraints. European Economic Review, 45(7):1121-1150.

Aghion, P., Bacchetta, P., and Banerjee, A. (2004). A corporate balance-sheet approach to currency crises. Journal of Economic Theory, 119(1):6-30.

Batini, N., Levine, P., and Pearlman, J. (2007). Monetary rules in emerging economies with financial market imperfections. In International Dimensions of Monetary Policy, NBER Chapters, pages 251-311. National Bureau of Economic Research, Inc.

Benigno, G. and Thoenissen, C. (2008). Consumption and real exchange rates with incomplete markets and non-traded goods. Journal of International Money and Finance, 27(6):926-948.

Benigno, P. (2009). Price stability with imperfect financial integration. Journal of Money, Credit and Banking, 41(s1):121-149.

Bernanke, B. S., Gertler, M., and Gilchrist, S. (1999). The financial accelerator in a quantitative business cycle framework. Handbook of macroeconomics, 1:1341-1393.

Born, B., Juessen, F., and Müller, G. J. (2013). Exchange rate regimes and fiscal multipliers. Journal of Economic Dynamics and Control, 37(2):446-465.

Bouakez, H. and Eyquem, A. (2015). Government spending, monetary policy, and the real exchange rate. Journal of International Money and Finance, 56:178-201.

Chang, R. and Fernández, A. (2013). On the sources of aggregate fluctuations in emerging economies. International Economic Review, 54(4):1265-1293.

Chang, R. and Velasco, A. (2001). Monetary policy in a dollarized economy where balance sheets matter. Journal of Development Economics, 66(2):445-464.

Cheng, G. (2015). Balance sheet effects, foreign reserves and public policies. Journal of International Money and Finance, 59:146-165.

Christiano, L. J., Gust, C., and Roldos, J. (2004). Monetary policy in a financial crisis. Journal of Economic Theory, 119(1):64-103. 
Cimadomo, J., Kirchner, M., and Hauptmeier, S. (2010). Transmission of government spending shocks in the euro area: Time variation and driving forces. Tinbergen Institute Discussion Paper, (10-021/2).

Corsetti, G., Meier, A., and Müller, G. (2012a). What determines government spending multipliers? IMF Working Paper, (12-150).

Corsetti, G., Meier, A., and Müller, G. J. (2012b). Fiscal stimulus with spending reversals. Review of Economics and Statistics, 94(4):878-895.

Devereux, M. B., Lane, P. R., and Xu, J. (2006). Exchange rates and monetary policy in emerging market economies. The Economic Journal, 116(511):478-506.

Eggertsson, G. B. and Krugman, P. (2012). Debt, deleveraging, and the liquidity trap: A Fisher-Minsky-Koo approach. The Quarterly Journal of Economics, 127(3):1469-1513.

Elekdăg, S. and Tchakarov, I. (2007). Balance sheets, exchange rate policy, and welfare. Journal of Economic Dynamics and Control, 31(12):3986-4015.

Enders, Z., Müller, G. J., and Scholl, A. (2011). How do fiscal and technology shocks affect real exchange rates?: New evidence for the United States. Journal of International Economics, 83(1):53-69.

Fernández-Villaverde, J. (2010). Fiscal policy in a model with financial frictions. American Economic Review, 100(2):35-40.

Forni, M. and Gambetti, L. (2016). Government spending shocks in open economy VARs. Journal of International Economics, 99:68-84.

Gechert, S. and Rannenberg, A. (2018). Which fiscal multipliers are regime-dependent? A meta-regression analysis. Journal of Economic Surveys, 32(4):1160-1182.

Gertler, M., Gilchrist, S., and Natalucci, F. M. (2007). External constraints on monetary policy and the financial accelerator. Journal of Money, Credit and Banking, 39(2-3):295330.

Huidrom, R., Kose, A., Lim, J. J., and Ohnsorge, F. L. (2020). Why do fiscal multipliers depend on fiscal positions? Journal of Monetary Economics, 114:109-125.

Ilzetzki, E., Mendoza, E. G., and Végh, C. A. (2013). How big (small?) are fiscal multipliers? Journal of Monetary Economics, 60(2):239-254. 
IMF (2011). Macroprudential policy: What instruments and how to use them? Lessons from country experiences. IMF Working Papers 11/238, International Monetary Fund.

Kim, S. (2015). Country characteristics and the effects of government consumption shocks on the current account and real exchange rate. Journal of International Economics, 97(2):436 $-447$.

Kim, S. and Roubini, N. (2008). Twin deficit or twin divergence? Fiscal policy, current account, and real exchange rate in the US. Journal of International Economics, 74(2):362383.

Kitano, S. and Takaku, K. (2015). Capital controls, monetary policy, and balance sheets in a small open economy. Discussion Paper Series DP2015-10, Research Institute for Economics \& Business Administration, Kobe University.

Kollmann, R. (2010). Government purchases and the real exchange rate. Open Economies Review, 21(1):49-64.

Levieuge, G. (2009). The bank capital channel and counter-cyclical prudential regulation in a DSGE model. Louvain Economic Review, 75(4):425-460.

Miyamoto, W., Nguyen, T. L., and Sheremirov, V. (2019). The effects of government spending on real exchange rates: Evidence from military spending panel data. Journal of International Economics, 116:144-157.

Monacelli, T. and Perotti, R. (2008). Openness and the sectoral effects of fiscal policy. Journal of the European Economic Association, 6(2-3):395-403.

Nickel, C. and Tudyka, A. (2014). Fiscal stimulus in times of high debt: Reconsidering multipliers and twin deficits. Journal of Money, Credit and Banking, 46(7):1313-1344.

Ravn, M., Schmitt-Grohé, S., and Uribe, M. (2012). Consumption, government spending, and the real exchange rate. Journal of Monetary Economics, 59(3):215 - 234.

Schmitt-Grohé, S. and Uribe, M. (2003). Closing small open economy models. Journal of International Economics, 61(1):163-185.

\section{Appendix}


Figure 4: Impulse response functions without a financial accelerator when $\omega=0.75$
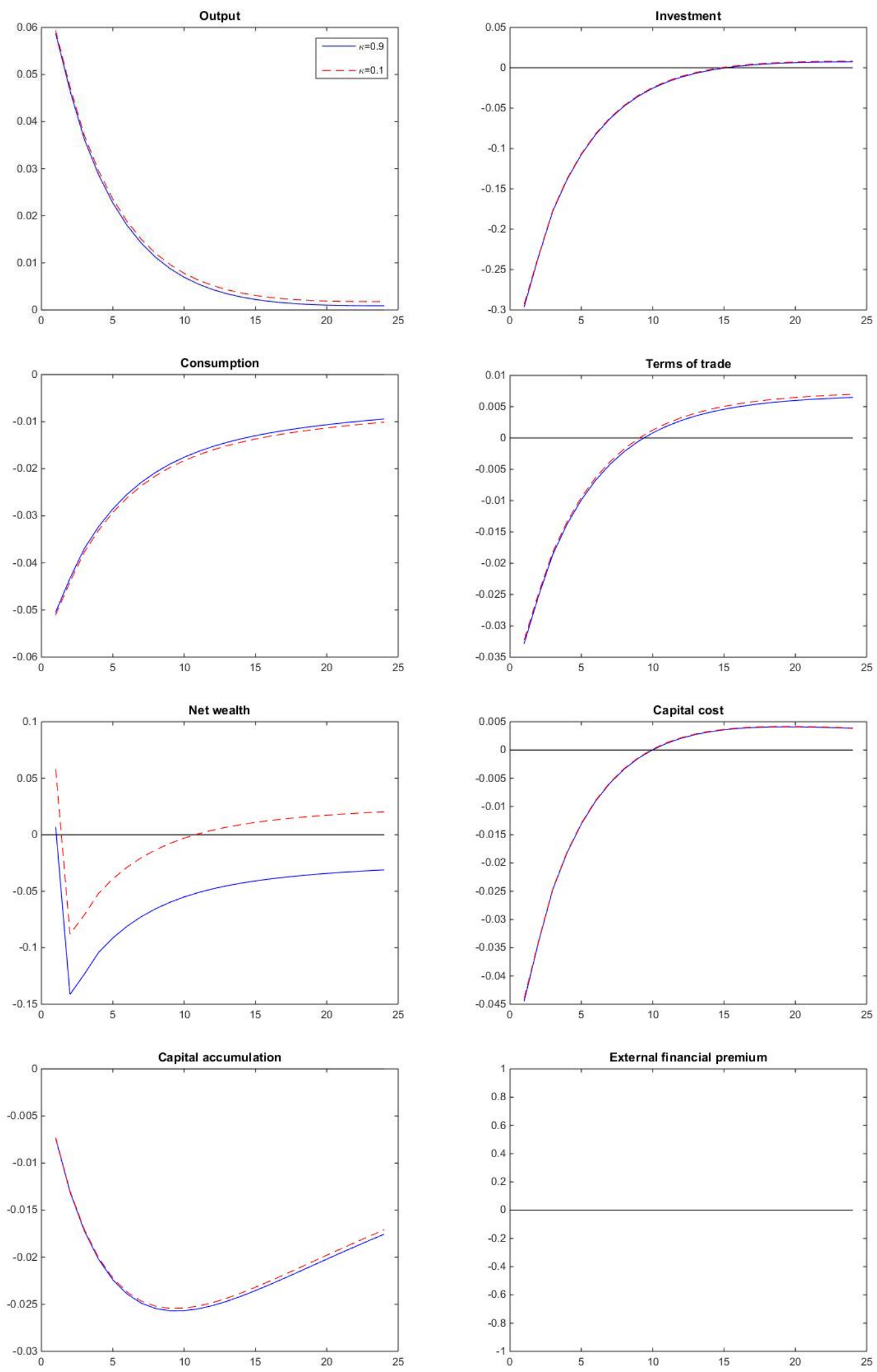
Figure 5: Impulse response functions without a financial accelerator when $\omega=0.25$
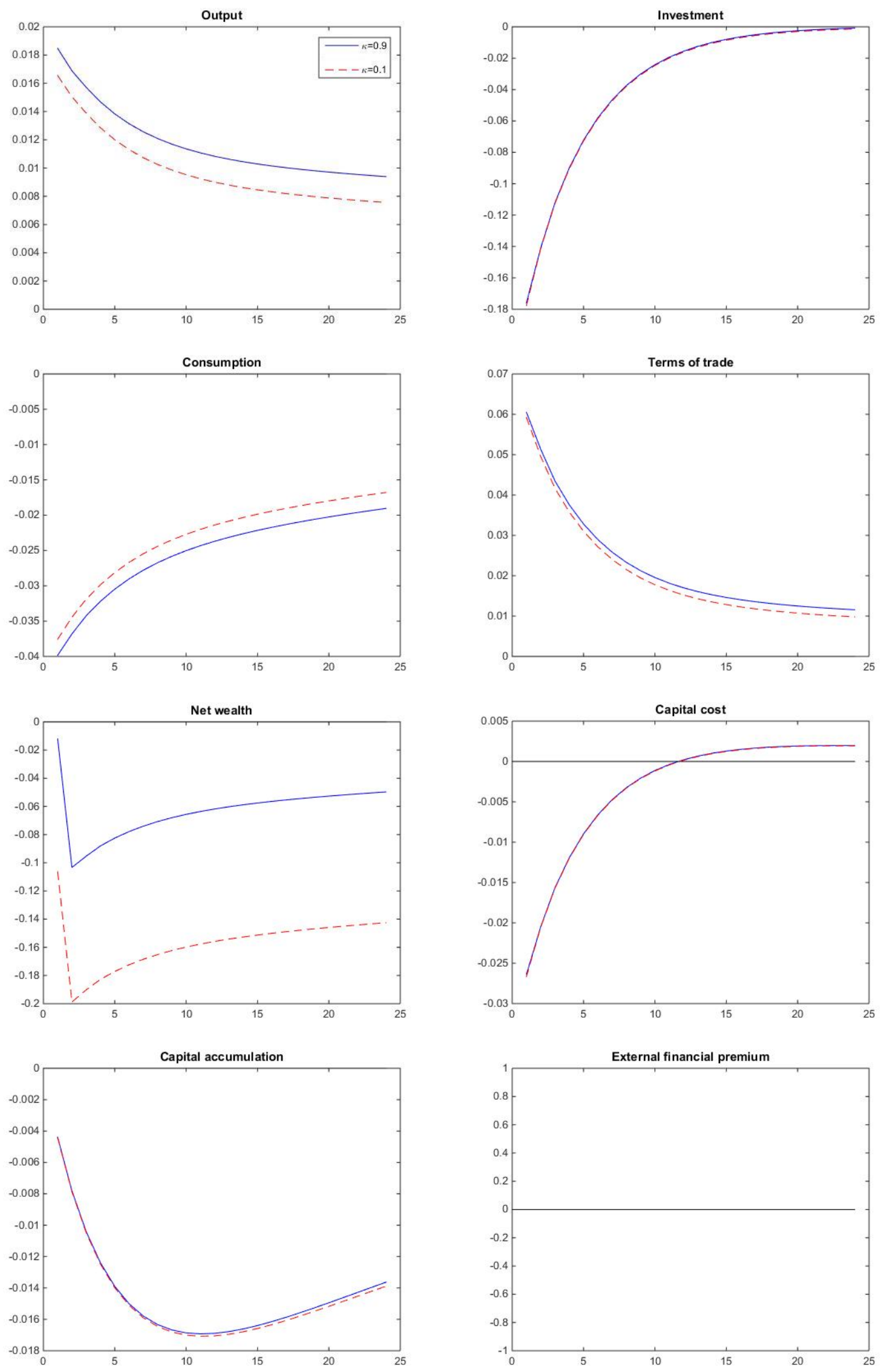


\section{The steady state}

Any variable without a time index refers to its steady-state value.

\section{Home economy}

$$
\begin{aligned}
& C=\left[w^{1 / \mu} C_{H}^{\mu-1 / \mu}+(1-w)^{1 / \mu} C_{F}^{\mu-1 / \mu}\right]^{\mu / \mu-1} \\
& C_{H}=w\left(\frac{P_{H}}{P}\right)^{-\mu} C ; \quad C_{F}=(1-w)\left(\frac{P_{F}}{P}\right)^{-\mu} C \\
& P=\left[w P_{H}^{(1-\mu)}+(1-w) P_{F}^{1-\mu}\right]^{1 /(1-\mu)} \\
& \tau=\frac{P_{F}}{P_{H}} \\
& I=\left[w^{1 / \mu} I_{H}^{\frac{\mu-1}{\mu}}+(1-w)^{1 / \mu} I_{F}^{\frac{\mu-1}{\mu}}\right]^{\frac{\mu}{1-\mu}} \\
& I_{H}=w\left(\frac{P_{H}}{P}\right)^{-\mu} I ; \quad I_{F}=(1-w)\left(\frac{P_{F}}{P}\right)^{-\mu} I \\
& \frac{I}{K}=\delta \\
& \frac{W L}{Y}=\frac{P_{H}}{P}(1-\alpha) \\
& q=1 \\
& \frac{Y}{K}=\frac{1}{\alpha} \frac{P}{P_{H}}\left[R^{k}-(1-\delta)\right] \\
& \frac{I}{Y}=\frac{\alpha \delta}{R^{k}-(1-\delta)} \frac{P_{H}}{P} \\
& R=\frac{1}{\beta}
\end{aligned}
$$




$$
\begin{gathered}
\Theta=\Theta\left(\frac{K}{N}\right) \\
R=R^{*} \\
R^{k}=\Theta R \\
C^{e}=\frac{\left(1-\xi_{e}\right)}{\xi_{e}} N \\
P G=T
\end{gathered}
$$

\section{Foreign economy}

$$
\begin{aligned}
& C^{*}=\left[(1-w)^{1 / \mu} C_{H}^{* \mu-1 / \mu}+w^{1 / \mu} C_{F}^{*^{\mu-1 / \mu}}\right]^{\mu / \mu-1} \\
& P^{*}=\left[(1-w) P_{H}^{*^{(1-\mu)}}+w P_{F}^{*^{1-\mu}}\right]^{1 /(1-\mu)} \\
& I^{*}=\left[(1-w)^{1 / \mu} I_{H}^{* \frac{\mu-1}{\mu}}+w^{1 / \mu} I_{F}^{* \frac{\mu-1}{\mu}}\right]^{\frac{\mu}{1-\mu}} \\
& I_{H}^{*}=(1-w)\left(\frac{P_{H}^{*}}{P^{*}}\right)^{-\mu} I^{*} ; \quad I_{F}^{*}=w\left(\frac{P_{F}^{*}}{P^{*}}\right)^{-\mu} I^{*} \\
& \frac{I^{*}}{K^{*}}=\delta^{*} \\
& \frac{W^{*} L^{*}}{Y^{*}}=\frac{P_{F}^{*}}{P^{*}}\left(1-\alpha^{*}\right) \\
& q^{*}=1 \\
& \frac{Y^{*}}{K^{*}}=\frac{P^{*}}{\alpha^{*} P_{H}^{*}}\left(R^{k *}-\left(1-\delta^{*}\right)\right) \\
& \frac{I^{*}}{Y^{*}}=\frac{\alpha^{*} \delta^{*}}{R^{k *}-\left(1-\delta^{*}\right)} \frac{P_{H}^{*}}{P^{*}}
\end{aligned}
$$




$$
\begin{gathered}
R^{*}=\frac{1}{\beta^{*}} \\
R^{k *}=R^{*} \\
\tau^{*}=\frac{1}{\tau} \\
\frac{P_{F}^{*}}{P_{F}}=\frac{P_{H}^{*}}{P_{H}}=1
\end{gathered}
$$




\section{Log-linearized model}

\section{Home economy}

Total demand (following Equation 29):

$$
\begin{aligned}
\widehat{Y}_{t}= & \mu(1-w) 2 w \widehat{\tau}_{t} \\
& +w\left(\frac{I}{Y} \widehat{I}_{t}+\frac{C^{e}}{Y} \widehat{C}_{t}^{e}+\frac{G}{Y} \widehat{G}_{t}+\frac{C}{Y} \widehat{C}_{t}\right) \\
& +(1-w)\left(\frac{I^{*}}{Y^{*}} \widehat{I}_{t}^{*}+\frac{C^{*}}{Y^{*}} \widehat{C}_{t}^{*}+\frac{G^{*}}{Y^{*}} \widehat{G}_{t}^{*}\right)
\end{aligned}
$$

Household consumption (following Equation 6):

$$
\widehat{C}_{t}=E_{t} \widehat{C}_{t+1}-\frac{1}{\sigma_{c}} \widehat{R}_{t}
$$

Capital demand (following Equation 21):

$$
\widehat{R}_{t}^{k}=\left(1-\frac{1-\delta}{R^{k}}\right) \widehat{m p} c_{t}-\frac{\Phi \delta^{2}}{R^{k}} \widehat{K}_{t}+\frac{1-\delta}{R^{k}} \widehat{q}_{t}-\hat{q}_{t-1}
$$

Expected cost of capital (following Equation 23):

$$
\widehat{R}_{t+1}^{k}=\theta\left(\widehat{q}_{t}+\widehat{K}_{t+1}-\widehat{N}_{t+1}\right)+\Theta \kappa \frac{R}{R^{k}} \widehat{R}_{t}+\Theta(1-\kappa) \frac{R^{*}}{R^{k}}\left(\widehat{R}_{t}^{*}+\widehat{\tau}_{t+1}-\widehat{\tau}_{t}-\phi_{d} \widehat{d}_{t}\right)
$$

Real price of capital (following Equation 18):

$$
\widehat{q}_{t}=\frac{\Phi \delta\left(\widehat{I}_{t}-\widehat{K}_{t}\right)}{q}
$$

Consumption of exiting firms (following Equation 25):

$$
\widehat{C}_{t}^{e}=\widehat{N}_{t}
$$

Marginal productivity of capital (following Equation 21):

$$
\widehat{m p} c_{t}=\widehat{Y}_{t}-\widehat{K}_{t}-(1-w) \widehat{\tau}_{t}
$$

Production function (following Equation 19):

$$
\widehat{Y}_{t}=\widehat{a}_{t}+\alpha \widehat{K}_{t}+(1-\alpha) \widehat{L}_{t}
$$


Labor supply (following Equation 5):

$$
\widehat{L}_{t}=\frac{1}{\sigma_{l}}\left(\widehat{W}_{t}-\sigma_{c} \widehat{C}_{t}\right)
$$

Marginal productivity of labor (following Equation 20):

$$
\widehat{W}_{t}=\widehat{Y}_{t}-\widehat{L}_{t}-(1-w) \widehat{\tau}_{t}
$$

Terms of trade (following Equation 13):

$$
\widehat{\tau}_{t}=E_{t} \widehat{t}_{t+1}+\widehat{R}_{t}^{*}-\widehat{R}_{t}-\phi_{d} \widehat{d}_{t}
$$

Net foreign asset accumulation (following Equation 31): ${ }^{9}$

$$
\widehat{d}_{t}=\frac{1}{\beta} \widehat{d}_{t-1}-(1-w) \widehat{\tau}_{t}+\widehat{Y}_{t}-\frac{C}{Y} \widehat{C}_{t}-\frac{C^{e}}{Y} \widehat{C}_{t}^{e}-\frac{I}{Y} \widehat{I}_{t}-\frac{G}{Y} \widehat{G}_{t}
$$

Net worth accumulation (following Equation 24):

$$
\begin{aligned}
\frac{\widehat{N}_{t}}{\xi_{e}}= & R^{k} \frac{K}{N} \widehat{R}_{t-1}^{k}+R^{k} \theta\left(1-\frac{K}{N}\right)\left(\widehat{q}_{t-1}+\widehat{K}_{t}\right)+R^{k}\left(\theta\left(\frac{K}{N}-1\right)+1\right) \widehat{N}_{t-1} \\
& -\Theta(1-\kappa) R^{*}\left(\frac{K}{N}-1\right)\left(\widehat{\tau}_{t}-\widehat{\tau}_{t-1}+\widehat{R}_{t-1}^{*}-\phi_{d} \widehat{d}_{t-1}\right) \\
& -\Theta \kappa R\left(\frac{K}{N}-1\right) \widehat{R}_{t-1}
\end{aligned}
$$

Capital accumulation (following Equation 17):

$$
\widehat{K}_{t+1}=\delta \widehat{I}_{t}+(1-\delta) \widehat{K}_{t}
$$

Fiscal policy:

$$
\widehat{G}_{t}=\rho_{g} \widehat{G}_{t-1}+\varepsilon_{g_{t}}
$$

Productivity shock:

$$
\hat{a}_{t}=\rho_{a} \hat{a}_{t-1}+\varepsilon_{a_{t}}
$$

\footnotetext{
${ }^{9}$ Since $d=0, \widehat{d_{t}}$ denotes $d_{t}-d$. See Bouakez and Eyquem (2015).
} 


\section{Foreign economy}

Total demand:

$$
\begin{aligned}
\widehat{Y}_{t}^{*}= & \mu(1-w) 2 w \widehat{\tau}_{t}^{*}+w\left(\frac{C^{*}}{Y^{*}} \widehat{C}_{t}^{*}+\frac{I^{*}}{Y^{*}} \widehat{I}_{t}^{*}+\frac{G^{*}}{Y^{*}} \widehat{G}_{t}^{*}\right) \\
& +(1-w)\left(\frac{C}{Y} \widehat{C}_{t}+\frac{C^{e}}{Y} \widehat{C}_{t}^{e}+\frac{I}{Y} \widehat{I}_{t}+\frac{G}{Y} \widehat{G}_{t}\right)
\end{aligned}
$$

Household consumption:

$$
\widehat{C}_{t}^{*}=E_{t} \widehat{C}_{t+1}^{*}-\frac{1}{\sigma_{c}} \widehat{R}_{t}^{*}
$$

Capital demand:

$$
\widehat{R}_{t}^{k^{*}}=\left(1-\frac{\left(1-\delta^{*}\right)}{R^{k^{*}}}\right) \widehat{m p} c^{*}-\frac{\Phi \delta^{*^{2}}}{R^{k^{*}}} \widehat{K}_{t}^{*}+\frac{\left(1-\delta^{*}\right)}{R^{k^{*}}} \widehat{q}_{t}^{*}-\widehat{q}_{t-1}^{*}
$$

Expected cost of capital:

$$
\widehat{R}_{t}^{k^{*}}=\widehat{R}_{t}^{*}
$$

Real price of capital:

$$
\widehat{q}_{t}^{*}=\frac{\Phi \delta^{*}\left(\widehat{I}_{t}^{*}-\widehat{K}_{t}^{*}\right)}{q^{*}}
$$

Marginal productivity of capital:

$$
\widehat{m p} c_{t}^{*}=-(1-w) \widehat{\tau}_{t}^{*}+\widehat{Y}_{t}^{*}-\widehat{K}_{t}^{*}
$$

Terms of trade:

$$
\widehat{\tau}_{t}^{*}=-\widehat{\tau}_{t}
$$

Production:

$$
\widehat{Y}_{t}^{*}=\hat{a}_{t}^{*}+\alpha \widehat{K}_{t}^{*}+(1-\alpha) \widehat{L}_{t}^{*}
$$

Labor supply:

$$
\widehat{L}_{t}^{*}=\frac{1}{\sigma_{l}^{*}}\left(\widehat{W}_{t}^{*}-\sigma_{c}^{*} \widehat{C}_{t}^{*}\right)
$$

Real wage:

$$
\widehat{W}^{*}=\widehat{Y}_{t}^{*}-\widehat{L}_{t}^{*}-(1-w) \widehat{\tau}_{t}^{*}
$$

Capital accumulation:

$$
\widehat{K}_{t+1}^{*}=\delta^{*} \widehat{I}_{t}^{*}+\left(1-\delta^{*}\right) \widehat{K}_{t}^{*}
$$


Fiscal policy:

$$
\widehat{G}_{t}^{*}=\rho_{g}^{*} \widehat{G}^{*}{ }_{t-1}+\varepsilon_{g_{t}}^{*}
$$

Productivity shock:

$$
\hat{a}_{t}^{*}=\rho_{a}^{*} \hat{a}_{t-1}^{*}+\varepsilon_{a_{t}}^{*}
$$

